\title{
Impact of terrorism on managerial efficiency of heads of secondary schools in Khyber Pakhtunkhwa, Pakistan
}

\author{
Usman Ghani Khattak and Javed Iqbal \\ Sarhad University of Science and Technology, Peshawar, Pakistan. \\ Received 05 August, 2014; Accepted 19 March, 2015
}

\begin{abstract}
Terrorism has adversely affected the educational environment in Khyber Pakhtoon Khwa Province. This study was conducted to know the impact of Terrorism on managerial efficiency of heads of secondary schools in Khyber Pakhtoon Khwa that included Malakand, Mangawara, Dir, Hangu , Bannu and D I Khan which are the highly affected areas of terrorism. Sample of the study comprised 120 Heads of Secondary schools, 60 males and 60 females. A five point scale was designed for data collection. The study concluded that Terrorism has badly affected the managerial efficiency of secondary school heads. The morale of the school Heads is low. Government has to immediately devise a strategy to control the terrorism and the school heads are to be given administrative and managerial training to improve their managerial efficiency.
\end{abstract}

Key words: Impact, terrorism, managerial efficiency, head, secondary schools.

\section{INTRODUCTION}

Terrorism is an act of violence used by the individual group and state to achieve some political goals. The incident of World Trade Centre brought drastic changes in the world political scenario. Since Sept 11, 2001, the Geo Strategic Policies of the Asian countries have been facing ups and down. Resultantly, priorities and interests of the world community have changed. Foreign policies, defense strategies and economic relationship were made according to the world existing situation. Terrorism spread at various parts of Pakistan in general and at Khyber Pakhtoonkhwa Province (KPK) in particular. KPK has borders with tribal areas which links Pakistan with Afghanistan. Presentably, in Afghanistan, the NATO forces are fighting against Taliban and war has been extended up to the tribal areas of Pakistan.
Educational Management plays a key role in the education system of any country. Monroe (2012) considers educational management as a comprehensive effort dealing with the educational process. It deals with educational institutions and is concerned with human, material resources like: students, parents, teachers and other employees. Educational managers work as District Education Officers, Principals and Heads of the schools. The students' achievement always depends upon the effective and efficient performance of the school managers. They show their performance and efficiency when they are capable of fulfilling managerial responsibilities and when they are provided with ideal working environment. In Khyber PakhtunKhwa, the war on Terror has adversely affected the infrastructure of all

*Corresponding a uthor. E-mail: usmankrk62@yahoo.com

Authors agree that this artic le rema in pemanently open access under the terms of the Creative Commons Attribution License 4.0 Intemational Lic ense 
the organizations in general and of education in particular.

\section{Impact}

A marked effect or influence to have a strong and often bad effect on someone or something is called impact. Impact is defined as striking of one thing against another. Afghan war and Taliban factor has greatly affected the social, economic and law and order situation at Khyber Pakhtunkhwa Province.

\section{Head}

In secondary schools, principals, head masters and head mistresses are also called heads of secondary schools. Head, within the school, is a person responsible for education of students, planning and organizing the activities for the school and involves the community in the affairs of the school. Louis and Wahirstrom (2011) argued that heads have collective responsibility for student learning, help students in their academic achievements and express higher levels of professional satisfaction. Louis (2011) further added that heads improve students' achievement, their professional practice and at the same time they promote shared leadership. Govinda (2002) stated that heads are accountable for school educational programs, student support, school councils, parents and community involvement and organization of the school activities. School Head act as a leader, controller, administrator and manager of the school. Alvi (2005) has supported this statement that head is a person who interacts with staff in five leadership domains i.e. Human relations, instructional leadership, control, conflict resolution and decision making. School heads act as instructional leaders. They guide their teachers in class room activities which directly affects students' learning. Elmore (2004), Haline (2009 and Fullan, 2010) stated that when members of a team make the results from their common assessments, transparent, analyze those results collectively and discuss which strategy seem most effective, based on actual evidence of students' learning, they are using most powerful catalysts for improving instruction. A school head controls, organizes, manages the activities of the school and guides the teachers in instructional activities. He manages the accounts and financial matters, maintains liaison with the community for achieving the desired objectives of the school.

Reddy (2006) visualized that head of secondary school is in a position to affect attitude, social climate, morale, progress, cooperation and direction of efforts in the school. School head is responsible for all the activities of the school. School performance and effectiveness in achieving the educational out comes always depends upon the effectiveness and efficiency of the school head.
Branch et al. (2013) argued that teachers affect only students while heads affect all the students and the staff in the school. They further elaborated that management of teacher quality is an important pathway through which school head affects the school quality.

\section{Terrorism}

Terrorism is the systematic use of terror especially used to achieve some political games. It is a state of mind rather than activity. According to Hoffman (1998; Numberg, 2001; Martyn, 2002; Deen, 2005), terrorism is the unlawful use of force or violence by a person or an organized group against people or property with the intention of intimidation or coercion of societies or governments often for ideological or political reasons. Terrorism is as old as humans. It is willingness to use violence to affect politics. It is random violence against innocent people in order to intimidate them for political or other goals. Charles (2002) has defined terrorism as the calculated use or threat of violence to inculcate for, intended to intimidate governments or societies. It is the result of extremism which results in different forms of manifestation of violence. Rana (2005) described terrorism as a kind of violence or threat designed to create an atmosphere of fear and a trigger of clue to start war and thereby bring about some political change. Michael (2007) further elaborated terrorism as an organized system of intimidation especially for political ends.

In 2003, the US led NATO forces entered Afghanistan to curb the wave of terrorism and revenge the destruction of World Trade Centre in United States of America. A new era of destruction and chaos started in the region. The Talibanization Movement expanded terrorism in the region. Irshad (2011) stated that the 9/11 terrorist attacks, subsequent US invasion in Afghanistan and joining the US led coalition," War on Terror" by Pakistan changed the priorities of Jihadis. They turned their guns towards Pakistan. Pakistan became their strategic focal point as they regarded Pakistan as the main obstacle in their jihad against the occupation in Afghanistan. Abbas (2007) and Daraz (2008) argued that Taliban leadership disfavored Pakistan's support to United States. They embarked their journey to express their rage with the support of local people in different parts of the country especially in KPK.

The strategy of terrorists is to commit acts of violence that draws attention of the local population, government and world to their cause. Self Defense Training Homeless Security Terrorist Research Center (2003) described three perspectives of terrorism, the terrorist, the victims and the general public. Terrorists do not see themselves doing evil. They believe, they are legitimate combatants, fighting for what they believe in by whatever means possible. These terrorists have spread a wave of terror and fear among the various segments of the society. No 
one can work freely as the common man and government officials are afraid of Taliban attacks.

\section{Types of terrorism}

Terrorism and its various types have been defined by various writers in different ways and times. Amy (2010) has described different types of terrorism as State Terrorism, Bio Terrorism, Cyber Terrorism, Eco terrorism, Nuclear Terrorism and Narco terrorism.

\section{State terrorism}

States can use force or threat without declaring war to terrorize citizens and achieve some political goals.

\section{Bio-terrorism}

Bio-terrorism is the intentional release of toxic biological agents to harm and terrorize civilians in the name of a political or other cause. It includes the viruses, bacteria and toxins that could be used in an attack.

\section{Cyber terrorism}

The use of information technology to attack civilians and draw attention to their cause is called cyber terrorism. Computer and telecommunication systems are used as means of cyber terrorism.

\section{Eco-terrorism}

It is a kind of terrorism which describes violence in the interests of environmentalism.

\section{Nuclear terrorism}

It refers to different ways of using nuclear material as a terrorist tactics. It includes attacking nuclear facilities, purchasing nuclear weapons or finding ways to disperse radio-active material.

\section{Narco terrorism}

Violence used by the drug traffickers to influence government or prevent government efforts to stop drug trade. Terrorist groups use trafficking of drugs to fund their operations. This wave of terrorism has adversely affected the educational system in KPK province, especially in secondary education. School Heads cannot perform their duties freely. Resultantly, the academic duties of secondary school cannot achieve the students' achievements effectively.

\section{Secondary schools}

Secondary school is an institution where secondary education is imparted to the students from class VI to class X. Sadaf (2011) views secondary school as a school where students are prepared for obtaining Higher education or vocational training. The term secondary school is used in different areas and regions of the world. In Pakistan, at provinces of the Punjab, Sindh, Khyber Pakhtunkhwa, Baluchistan and Islam Abad capital territory, high schools impart secondary education from class $\mathrm{VI}$ to class $\mathrm{X}$. These schools are controlled by Directorate of Secondary Education. Examination system of these schools is conducted by Boards of Intermediate and Secondary Education Peshawar, Mardan, Swat, Abott Abad, Kohat, Bannu and DI Khan.

\section{Managerial efficiency}

Management is an act, manner or practice of managing and controlling the resources of the organization to achieve the desired output. It is a social process which is designed to ensure the cooperation, participation, invention and involvement of others in the achievements of the desired objectives. Dovell (2006) states that management is the process of achieving organizational goals through planning, organizing, leading, controlling the human, physical and financial resources of the organization in effective and efficient manner. School heads act as managers of the school. School manager interacts with staff in five leadership domains like instructional leadership, control and conflict resolution. Chris et al. (2009) described that school head is a person with balanced roles. He manages and controls the activities of the school through communication, motivation and Human Resource Management. School head is the manager of the school and responsible for achieving the students' achievements. He does all these activities through his management functions within the school. Khan (2009) supports the above statement that communication, motivation and human resource management are the three main equipment which helps to regulate the activities of the school managers. Efficiency of the school heads play key role in successful working of the school. Efficiency means getting maximum output by using minimum available resources within the organization. Marica (2013) has defined efficiency as obtaining maximum possible output for any given expenditure of the resources. In secondary schools, the heads utilize the government funds and the services of the teachers and the staff to get students' achievements. 
According to Mouer (2006), managerial efficiency is the full measure of the combined effects of management, Teaming and leadership skill on corporate productivity. In Managerial Efficiency, the concept efficiency is a numerical score achieved by multiplying the score achieved on managerial skills by the score achieved on leadership skill and teaming skill. Jennis and Geipele (2006, p.175) are of the view that managerial efficiency is a comparative valuation of the utilized resources with the result achieved by the manager with in the school. In this study the available and utilized resources like buildings, teachers and other facilities were examined and compared with the students' success rate.

\section{Terrorism in Khyber Pakhtoon Khwa}

In 1979, the Russian forces entered Afghanistan. The world was divided in two blocks at that time i-e Capitalist and communist. USA and her allies reacted against USSR intervention in Afghanistan. They started war against USSR in Afghanistan and used Pakistan as front line state. The Province of KPK at that time NWFP directly touches the border with Afghanistan. Mujahdeen was created, trained and used to fight against Russian forces in Afghanistan. Headquarters of these Mujahedeen groups were at Peshawar. Thirty five lacs (3.5M) Afghan Refugees were given shelters at various places of KPK. Resultantly, the enemy agents started bomb blast at Peshawar and interior KPK. A huge quantity of Russian arms was smuggled. It led to a wave of terrorism, since that the overall infrastructure of KPK in general and of education in particular was destroyed.

In 2003, NATO forces entered Afghanistan and launched operations against Taliban. This war extended up to the Province of Khyber Pakhtoon Khwa.Since 2003, till the date about 3000 schools buildings have been destroyed fully or partially. A large number of principals, teachers and students have been killed. According to Alan (2005) Al Qaeeda forces that fled from Afghanistan with their Taliban supporters remained active on Pakistan's territory. Al Qaeda is believed to have links with indigenous Pakistani terrorist groups. A significant portion of Pushtun population is reportedly having sympathies with Taliban and Al-Qaeda. According to CSR Report for Congress (2003), Al-Qaeda has reportedly made alliance within indigenous Pakistan terrorist groups that have been implicated in both anti Western attacks in Pakistan and Khyber Pakhtoon Khwa Province. Various research studies have proved that terrorism is a criminal act that influences an audience beyond the immediate Igwe (2004) and Obanya (2006) have identified inadequate number of qualified teachers, irregular payment of teachers' salaries and dissatisfaction with the conditions of service as obstacle to Heads managerial efficiency in Public secondary schools. In addition to their salary and other problems, terrorism has badly affected their professional performance and their managerial efficiency.

\section{Impact of terrorism}

Terrorism has adversely affected the organizational structure of the secondary schools in KPK. According to Lunenburg and Ornstein (2008), the principals work with students, teachers, parents and other school staff to set up organization's structures and help to develop other people of school by delegating powers and very carefully monitoring the management functions in the school. Pakistan is a front line state in a war against terrorism and confronting severely terrorist attacks. These attacks have shaken the social fabric, hampered economic progress and weakened the political system. Michael (2007) elaborated that terrorism is a political phenomenon with special reference to Pakistan. Irshad (2011) described that terrorism is a great hurdle in our socio-economic prosperity, political stability and geographic sustainability. Bachar (2006) and Bhatto (2008) argued that inclination to use terrorism is thought to be reduced when the political process is open to the expression of diverse viewpoints. In Pakistan, the political system is not still mature. The politicians do not the play key role in strengthening the political system of the country. They cannot decide how to deal with terrorism issues and to minimize its impacts. Saigol (2010) pointed out that terrorism has brought enormous crisis in South Asian countries through the adverse impacts on the social, economic, political and physical infrastructure. Since 2003, the physical infrastructure of the school buildings has been damaged by the terrorists' bomb blasts. Daraz (2008) stated that terrorism has threatened internal and external security where the crime-corruption nexus adds to the political complexities. The settled and FATA regions in Pakistan are not safe due to internal threats of the security. Terrorists are killing law enforcement officials, civilians and destroying the physical infrastructure of educational institutions and government buildings. Khan (2009) highlighted that Pakistan was unfamiliar to terrorist activities prior to 9/11 but when Pakistan decided to participate in the "Global War on Terror" (GWOT) it led to serious blow to domestic security and instability in the country. Since 2007, 12456 innocent people were killed, 14775 injured and 10,000 militants killed. 733 school buildings have been destroyed or partially damaged

Siddiqui (2007) considered that adverse impacts of terrorism are observable upon the social, economic, political, financial and infrastructural aspects of the area. The increasing terrorist attacks led to military operations in the terrorism affected areas like Swat, Dir, Khyber Agency and South Waziristan. This led to various social problems. Thousands of people became homeless and the people migrated from one place to another. Daily The 
NEWS article published in (2009) supported this statement that military operation worsened the condition in the form of huge mass-displacement and migration in Khyber Pakhtun Khwa

\section{Objectives of the study}

i To investigate the managerial efficiency of heads of secondary schools in Khyber Pakhtunkhwa Province.

ii To know the impact of terrorism on managerial efficiency of heads of secondary schools in KPK

iii To make recommendations for improving managerial efficiency of secondary school heads in KPK

\section{Statement of the problem}

In Pakistan in general and Khyber PakhtoonKhwa in particular, terrorists' activities have damaged the entire infrastructure of education. The buildings are damaged and teachers have been killed. There is uncertainty within the educational administration and management. It was needed to analyze the impact of terrorism on managerial efficiency of secondary school heads in KPK.

\section{METHOD}

\section{Population}

According to Eisenberg et al. (2007) population is a statistical form which means all the units (people, items, and events) from which the sample can be drawn. Naizaro, (2012) further elaborated that population is an accessible group of people who meet a well defined set of eligibility criteria. Population of the study included 321 Heads of Secondary Schools (both genders) from 06 districts of KPK Province, Pakistan namely Swat, Dir, Malakand, Hangu, Bannu and DI Khan.

\section{Sample}

Kennedy (2005) viewed that sampling in educational research is generally conducted in order to permit the detailed study of the part rather than the whole of the population. Mertens (2005) added that sample size may be determined on the basis of the judgment of the researcher. Sample of the study comprised 06 districts of Swat, Dir, Peshawar, Hangu, Bannu and DI Khan. 120 Heads of secondary school Heads were selected out of 321 secondary schools. Sample was taken on the basis of highly affected districts of terrorism.

\section{Instrumentation and Data Collection}

A Questionnaire was developed on 5 points Likert's scale. Jackson (2009) stated that many researchers prefer to use a Likert type scale because it is easy to statistically analyze the data. Validity of the Questionnaire was confirmed by calculating the Cronbach Alpha value. The questionnaire was administrated to 120 Heads of Schools. Researcher personally visited, collected and recorded the data. The data was analyzed through a statistical means. Means and Standard Deviation were calculated (Table 1).
Table 1. Mean and standard deviation of school heads on managerial efficiency scale.

\begin{tabular}{lccc}
\hline Variable & F & Means & SD \\
\hline Motivation & 120 & 2.90 & 0.7 \\
Teachers' facilitation & 120 & 2.10 & 1.01 \\
Organization & 120 & 4.29 & 0.8 \\
Coordination & 120 & 2.60 & 1.09 \\
Liaison with Heads & 120 & 3.20 & 1.05 \\
Liaison with community & 120 & 2.9 & 0.9 \\
Commitment & 120 & 3.98 & 1.01 \\
Morale & 120 & 2.46 & 0.83 \\
Terrorism impact & 120 & 3.94 & 1.02 \\
\hline
\end{tabular}

\section{FINDINGS}

It was found that heads of secondary schools failed to motivate teachers and students for better results, to plan and organize the activities of the school and facilitate teachers for improving the instructional activities; they could not coordinate with the community as well as the neighboring school heads. Heads agreed that they were committed to their job but disagreed that their morale was high. They agreed that terrorism has adversely affected the managerial efficiency of secondary school heads in KPK.

\section{Conclusion}

It was concluded that terrorism is the main issue which has directly and indirectly affected the performance of the Heads of secondary schools. Terrorism is the main hurdle in improving the managerial efficiency of school Heads. School heads are to concentrate on motivation of their teachers, coordinate with their colleagues and take steps to keep up the morale of their staff. Government needs to take steps to control terrorists' activities and train the heads according to the existing situation. The heads need administrative and managerial trainings and the management academies are also to be established by the KPK Government.

\section{RECOMMENDATIONS}

Government has to take immediate steps to resolve terrorism problem and bring Peace in KPK and FATA regions. Management academies for educational management are to be established where administrative and managerial training will be given to the secondary school heads. It will improve the managerial efficiency of secondary school heads

\section{Conflict of Interests}

The author has not declared any conflict of interests. 


\section{REFERENCES}

Abbas H (2004) Pakistan's drift into extremism; Allah the Army and Americans war on Terror, Armonk; ME. Sharpe.

Alan K (2005) Terrorism in South Asia. Report for Congress. Congressional Research services (CSR), Library of congress (USA).

Bhatto B (2008). Reconcilation: Islam, Democracy and the West, 24 Distinguished Lecture series. Otto/ ljanikin: Adnerian Ogunsanya College of Education

Branch GF, Hanushek EA, Rivkin SG (2013). Measuring the impact of effective principals. Education Next Vol. 13, No. 1. http://educationnext.org/school-leaders-matter/

Charles T (2002) A History of Iraq - Second Edition. Cambridge University Press (UK).

Daraz U (2008) Community Response towards Taliban Movements, Unpublished BS (Hons) thesis, Department of sociology; University of Malakand

Deen T (2005) Politics: UN Member State struggle to define terrorism. Inter Press service.

Eisenberg D, Gollust SE, Golberstein E, Hefner JL (2007). prevalence and Correlates of depression, anxiety and suicidity among university students; American journal of Orthopsychiatry, 77(4):534-542.

Elmore RF (2004). School Reform from the Inside Out: Policy, Practice, and Performance. Cambridge, MA: Harvard Education Press.

Fullan M (2010). All (systems(go.(Thousand Oaks, CA. Corwin Press; Toronto: Ontario!Principals!Council.

Hoffman N (1998) Inside Terrorism Columbia University Press. ISBN 0231-1148-

Irshad M (2011). Terrorism in Pakistan: Causes \& Remedies. The Dialogue, Volume VI Number 3.

Jackson SL (2009). Research methods and statistics: A critical thinking approach (3rd ed) Belmont, CA: Wardswarth.

Jennis $\vee 7$ Geipele int (2006) Assessment of managerial efficiency. Raga Technical University 2006(6), 175-182.

Kennedy $\mathrm{CH}$ (2005). Single case-research designs for educational research. Boston: Pearson education Inc.

Khan MK (2009). Analyzing Domestic Terrorism as a threat to Pakistan security and the policy Response IPR J. 9, no

Lunenburg FC, Ornstein AO (2008). Educational administration: Concepts and practices (5th ed.). Belmont, CA: Wadsworth/Cengage.

Martyn H (2002). Educational Research, Policymaking and Practice. London: Paul Chapman.
Mertens DM (2005). Research methods in education and psychology: Integrating diversity with quantitative and qualitative approaches (2nd ed) Thousand Oaks: Sage.

Michael S (2007). Terrorism a Socio-Economic and Political Phenomenon with Special Reference to Pakistan. J. Manage. Soc. Sci. 3(1):35-46.

Naizaro LM (2012). Sample and Sampling Techniques. Retrieved from www.slideshare.net/ludymae/chapter-8 sample-sampling-techniques.

Numberg (2001) Head Games started with Robespierre terrorism. The history of The very frightening world. San Francisco Chronicle. http:// articles.sfgate.com/2001-10

Obanya (2006) Teaching without teacher, 24 Distinguished Lecture series. Otto/ljanikin: Adnerian Ogunsanya college of Education.

Rana (2005) The seed of Terrorism; London: new Millennium Rousmaniere K. (2013) The Principal's Office; A Social History of the American School Principal: Sunny Press, US

Reddy M (2006) Research paper on managerial efficiency A product of Leadership, management \& Teaming skills.

Saigol (2010). Radicalization of state and society in Pakistan. Heinrich Boll shifting Pakistan.

Siddiqui A (2007). Pakistan on Red Alert against possible Militant Black Lash. Daily Times 11 July, 2007. 